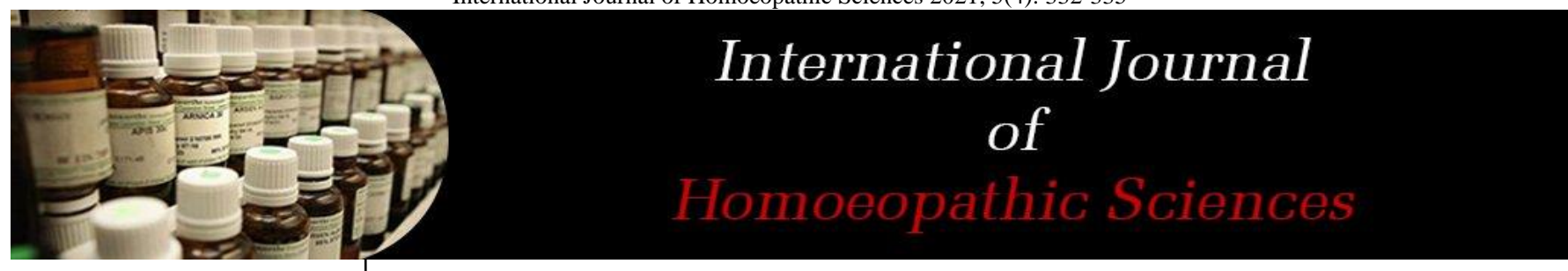

E-ISSN: $2616-4493$

P-ISSN: 2616-4485

www.homoeopathicjournal.com IJHS 2021; 5(4): 332-335

Received: 28-07-2021

Accepted: 30-09-2021

Dr. B Sree Likhitha

Dept of Paediatrics PG Part 2.

Guru Mishri Homoeopathic

Medical College, Jalna,

Maharashtra, India
Corresponding Author: Dr. B Sree Likhitha

Dept of Paediatrics PG Part 2.

Guru Mishri Homoeopathic

Medical College, Jalna,

Maharashtra, India

\section{A case report of ingrown toe nail}

\section{Dr. B Sree Likhitha}

DOI: $\underline{\text { https://doi.org/10.33545/26164485.2021.v5.i4e.494 }}$

\section{Abstract}

Ingrown toe nail also known as onychocryptosis is a common nail condition that occurs due to curling of the side of the nail into the periungual dermis. Management options range from conservative treatment like gutter splint technique to extensive surgical approaches dictated by the severity and the stage of the condition. This case study is an attempt at explaining that homoeopathy can bring about a cure even in some surgical conditions. This case shows a marked improvement with no recurrence.

Keywords: ingrown toe nail, onychocryptosis, homoeopathy, acid fluor

\section{Introduction}

Onychocryptosis is taken from the Greek work onyx meaning nail and Kryptos meaning hidden. It is also known as ingrown toe nail, embedded toe nail or Unguis incarnatus. It is a common nail condition which occurs when the nail fold (periungual skin) is penetrated by the edge of a nail plate. It is commonly seen in the teenagers and young adults during the second and third decades of life. It causes pain, discomfort and, disability when left untreated. Diagnosis is apparent and several treatment approaches exist from conservative treatment like taping, nail braces, antibiotics, packing, dental floss and gutter to extensive surgical treatment options chosen by the severity and the stage of ingrown toe nail.

\section{Aetiopathogenesis}

The widely accepted theory is that onychocryptosis occurs when the lateral nail fold is penetrated by the edge of the nail plate causing pain, sepsis and formation of the granulation tissue. Multiple theories have been proposed in relation to the aetiology and can be broadly classified according to whether the primary cause is related to nail or the soft tissue at the side of the nail.

The common predisposing factors implicated in the development of an ingrown toe nail are: Improperly trimmed toe nails,

Poorly fitting shoes,

Excessive sweating,

Nail infection,

Nail apparatus abnormalities,

Others include congenital onychocryptosis and sub ungual neoplasms and trauma.

\section{History and physical examination}

The history of chronology, prior trauma, foot wear, occupation, sports activities should be included in the case taking. The assessment of pain at rest, standing and ambulating must be noted. Proper physical evaluation of nails while the patient is upright and during the gait should be examined.

The diagnosis is classically based on the clinical features and does not require any laboratory or radiographic tests.

The ingrown toe nails are classified into 3 stages depending on the severity. Stage 1: Nail fold swelling, edema, erythema and pain exacerbated by pressure.

Stage 2: Swelling, pain, inflammation along with an active/acute infection. Presents as granulation tissue, seropurulent discharge or ulceration of the nailfold. 
Stage 3: Chronic inflammation with formation of epithelialized granulation tissue with marked nail fold hypertrophy.

\section{Their recent classification of Mozena has described} onychocryptosis into 4 stages

i. Inflammatory

ii. Abscess stage

iii. Hypertrophic stage

iv. Distal hypertrophic stage.
Differential diagnosis

Subungual exostosis

Primary osteoporosis of phalanx

Tumors of the nailbed (benign and malignant)

\section{Case report}

A 37-year-old female came to the opd with the complaints of pain in the $1^{\text {st }}$ tow for past 15 days, was diagnosed as ingrown toe nail by a dermatologist and treated symptomatically which gave a temporary relief from pain but no satisfactory improvement.

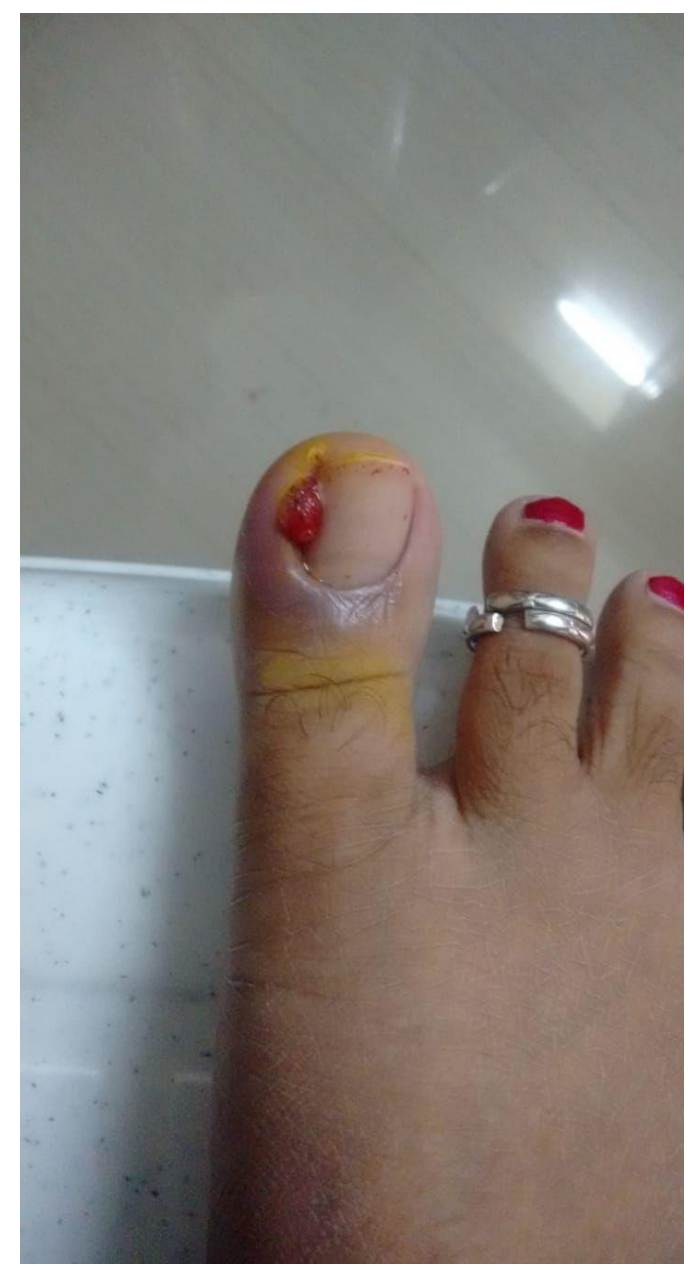

When the patient $1^{\text {st }}$ presented with complaint.

\section{History of presenting complaints}

Patient had a similar complaint of ingrown toenail 1 year ago, used allopathic and ayurvedic treatment which subsided the complaint.

\section{Past history}

Patient had jaundice at 12 years age.

She has decayed and hollow tooth since 3 years on allopathic treatment with no improvement.

\section{Family history}

Mother has hypertension and father expired due to cardiac arrest.

\section{Physical generals}

Appetite: satisfactory

Thirst: 2-31ts/day.

Aversion: pungent things
Urine: 4-5/day;0-1/night

Sleep: 7-8hours/day, sound sleep, uncovers foot at night.

\section{Female}

Menarche: 13years age.

30/4days, regular cycle.

All pregnancies normal, full-term deliveries. (G3A1L2P2)

\section{Mental generals}

She has fear of poverty and indifference to the business affairs and she is sensitive to noise.

Clinical diagnosis: ingrown toe nail.

Selection of remedy: medicine was selected and prescribed to the patient on the basis of repertorisation. The case was repertorised with synthesis repertory using Radar opus 2.2.16 software. 


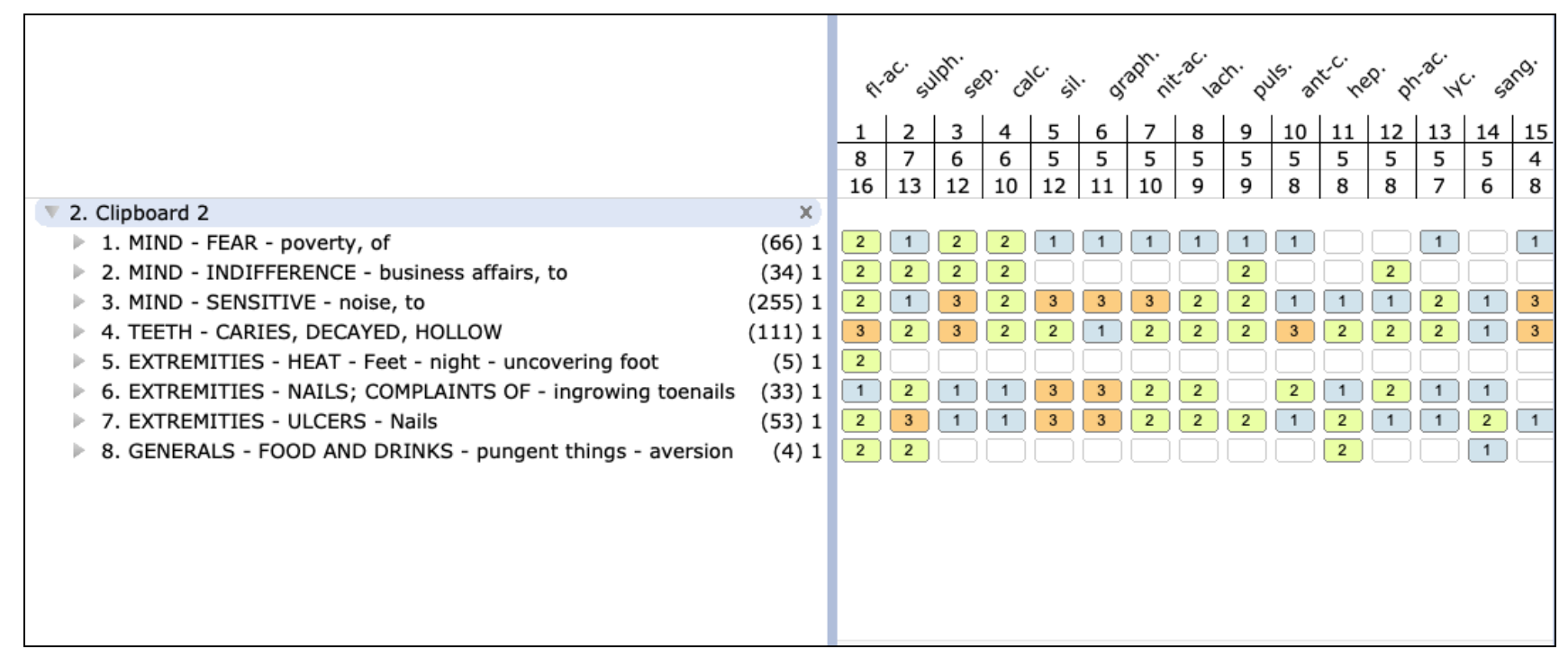

Repertorial sheet

Remedy selected:

Acid fluor $200 \mathrm{ch}$

Prescription:

Acid fluor/200/OD/3days.

SL for 15 days

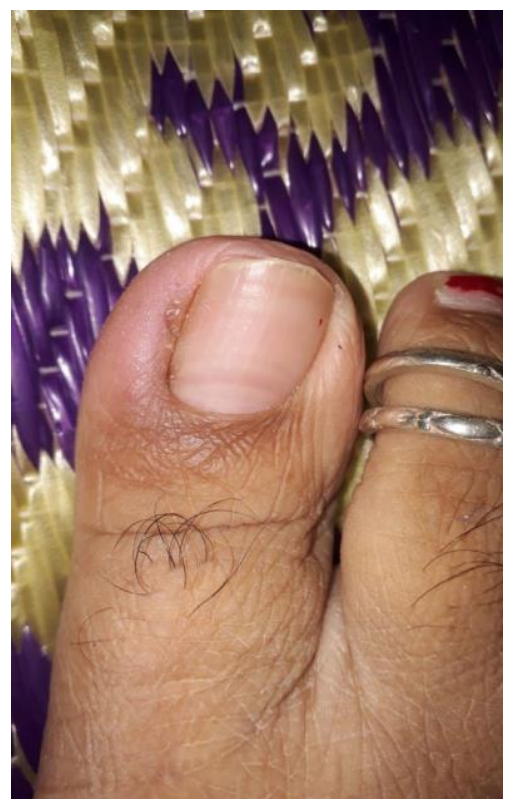

After treatment with acid fluor/200.

\section{Conclusion}

The patient was reviewed after 15 days and the swelling and the pain reduced so the patient was given SL for next 15 days. It has been 3 years with no recurrence of ingrown toe nail. And we can observe change in her decayed tooth which was unreactive before homoeopathy. This case study is an attempt at explaining that homoeopathy can bring about a cure even in some surgical conditions.

\section{References}

1. Murtagh J. "Patient education. Ingrowing toenails," Australian family physician 1993;22(2):206 View at: Google Scholar

2. Siegle RJ, Stewart R. "Recalcitrant ingrowing nails: surgical approaches," Journal of Dermatologic Surgery and Oncology 1992;18(8):744-752. View at: Google Scholar

3. Khunger N, Kandhari R. Ingrown toenails. Indian $\mathbf{J}$ Dermatol Venereol Leprol 2012;78:279-89. [PMID: 22565427].

4. Eekhof JA, Van Wijk B, Knuistingh Neven A, van der Wouden JC. Interventions for ingrowing toenails. Cochrane Database Syst Rev 2012; Cd001541. [PMID: 22513901].

5. Borges APP, Pelafsky VPC, Miot LDB, Miot HA. Quality of Life With Ingrown Toenails: A CrossSectional Study. Dermatol Surg 2017;43:751-3. [PMID: 28291066].

6. DeLauro NM, DeLauro TM. Onychocryptosis. Clin Podiatr Med Surg 2004;21:617-30. [PMID: 15450901]

7. Erdogan FG, Guven M, Erdogan BD, Gurler A. Previous nail surgery is a risk factor for recurrence of ingrown nails. Dermatol Surg 2014;40:1152-4. [PMID: 25255279]

8. Yang G, Yanchar NL, Lo AY, Jones SA. Treatment of ingrown toenails in the pediatric population. J Pediatr Surg 2008;43:931-5. [PMID: 18485969]

9. Heifetz CJ. Operative management of ingrown toenail. Mo Med 1945;42:213-6. [PMID: 21007315].

10. Ezekian B, Englum BR, Gilmore BF, Kim J, Leraas HJ, Rice HE. Onychocryptosis in the Pediatric Patient. Clinical pediatrics. 2017. [PubMed PMID: 27941086]

11. Khunger $\mathrm{N}$, Kandhari $\mathrm{R}$, Ingrown toenails. Indian journal of dermatology, venereology and leprology. 2012. [PubMed PMID: 22565427]

12. James WD, Berger T, Elston D. Diseases of the skin appendages. In: James WD, Berger T, Elston D, editors. Andrews' Diseases of the Skin: Clinical Dermatology. 10 th ed. Philadelphia, PA: Elsevier/Saunders. 2006, 749-93.

13. Baran R, Haneke E, Richert B. Pincer nails: Definition and surgical treatment. Dermatol Surg 2001;27:2616.[Google Scholar]

14. Chapeskie H. Ingrown toenail or overgrown toe skin? Alternative treatment for onychocryptosis. Can Fam Physician 2008;54:1561-2.[Google Scholar]

15. Lemont $\mathrm{H}$, Brady J. Amelanotic melanoma masquerading as an ingrown toenail. J Am Podiatr Med Assoc 2002;92:306-7.[Google Scholar] 
16. Goldenhersh M, Prus D, Ron N. Merkel cell tumour masquerading as granulation tissue on a teenager's toe. Am J Dermatopathol 1992;14:560-3.[Google Scholar]

17. Martínez-Nova A, Sánchez-Rodríguez R, Alonso-Peña D. A new onychocryptosis classification and treatment plan. J Am Podiatr Med Assoc 2007;97:389-93.[Google Scholar]

18. Bhat, SRB textbook of surgery

19. Schroyens, Synthesis repertory radar version 2.2 .16

20. https://www.hindawi.com/journals/isrn/2012/438915/=

21. Chapeskie H, Kovac JR. Soft-tissue nail-fold excision: A definitive treatment for ingrown toenails. Can J Surg 2010;53:282-6. [Google Scholar]

22. Noel B. Surgical Treatment of Ingrown Toenail without Matricectomy. Dermatol Surg 2008;34:79-83.[Google Scholar]

23. Aksakal AB, O'zsoy E, Gurer MA. Silicone gel sheeting for the management and prevention of onychocryptosis. Dermatol Surg 2003;29:2614.[Google Scholar]

24. Monheit GD. Nail surgery. Dermatol Clin 1985;3:52130.[Google Scholar]

25. Brown FC. Chemocautery of ingrown toenails. J Dermatol Surg Oncol 1981;7:331-3.[Google Scholar]

26. Eisele SA. Conditions of the toenails. Orthop Clin North Am 1994;25:183-8.[Google Scholar]

27. Burzotta JL, Turri RM, Tsouris J. Phenol and alcohol chemical matrixectomy. Clin Podiatr Med Surg 1989;6:453-67.[Google Scholar]

28. Reyzelman MA, Trombello AK, Vayser DJ, Armstrong DG, Harkless BL. Are antibiotics necessary in the treatment of locally infected ingrown toenails? Arch Fam Med 2000;9:930-2.[Google Scholar]

29. Wolf EW, Hodge W, Spielfogel WD. Periungual bacterial flora in humanfoot. J Foot Surg 1991;30:25363.[Google Scholar]

30. Ogur R, Tekbas OF, Hasde M. Managing infected ingrown toenails: Longitudinal band method. Can Fam Physician 2005;51:207-8. [Google Scholar] 